\title{
Genetic structure of candidate genes for litter size in Italian Large White pigs
}

\author{
S. Dall'Olio • L. Fontanesi • L. Tognazzi • V. Russo
}

Published online: 15 May 2010

(C) Springer Science+Business Media B.V. 2010

\begin{abstract}
The aim of this work was to verify whether polymorphisms in candidate genes for litter size segregate in Italian Large White (ITLW) pigs. We genotyped 120 sows that belonged to six different farms for 10 single nucleotide polymorphisms (SNPs) of 10 different genes. Polymorphisms in the chosen genes had already been associated with litter-size traits in other pig populations and were candidates for function and/or chromosomal location. The results indicated that the CLGN, $p D A Z L$, and RFN4 SNPs were not segregating in the genotyped samples. The remaining seven markers were polymorphic with minor allele frequencies ranging from 0.10 $(A F P)$ to 0.48 (RBP4). Because of the observed genetic variabilities in the investigated loci, the polymorphisms in the AFP, BMPR1B, CXCL10, ESR2, GNRHR, MAN2B2, and RBP4 genes can be considered suitable markers for association studies with litter-size traits in ITLW pigs.
\end{abstract}

Keywords SNP· Genetic variability · Pig · Italian Large White

\author{
Abbreviations \\ ITLW Italian Large White \\ MAF Minor Allele Frequency \\ MAS Marker Assisted Selection \\ QTL Quantitative Trait Loci \\ SNP Single Nucleotide Polymorphism \\ SSC porcine chromosome \\ UTR Untranslated Region
}

\section{Introduction}

Litter size is a complex quantitative trait that is mainly measured as the number of piglets born. However, several other traits, which are more difficult to detect such as ovulation rate, number of corpora lutea, uterine capacity, embryonic, and fetal survival, influence its

S. Dall'Olio $(\bowtie) \cdot$ L. Fontanesi $\cdot$ L. Tognazzi $\cdot$ V. Russo

Dipartimento di Protezione e Valorizzazione Agroalimentare, Università degli Studi di Bologna,

Sezione di Allevamenti Zootecnici, Via F.lli Rosselli 107, 42123, Reggio Emilia, Italy

e-mail: stefania.dallolio@unibo.it 
variability. All these reproductive traits are expressed only in females and after sexual maturity. These biological characteristics and their low heritability limit the effectiveness of selection for prolificacy. Marker-assisted selection (MAS) could be an important tool for genetic improvement of litter size. A few candidate genes for litter size have been already identified in pigs according to their roles in the physiology of reproduction and/or their position within chromosomal regions containing quantitative trait loci (QTL) for reproductive traits (Distl 2007). To use these markers in MAS, it is necessary to verify whether these markers are associated with the traits in the specific population under selection. However, as a preliminary step, it is important to evaluate whether the markers are polymorphic in the investigated populations. Here, we analyzed polymorphisms in 10 candidate genes for litter size in Italian Large White (ITLW) pigs to evaluate their usefulness for association studies.

\section{Materials and methods}

Hair samples were collected from 120 ITLW sows from different herds in the EmiliaRomagna and Lombardy regions. The samples were used for the extraction of genomic DNA. Markers in 10 loci identified from the literature were analyzed (Table 1). Single nucleotide polymorphisms (SNPs) were analyzed with a Sequenom Iplex TM GOLD system that combines primer extension with mass spectrometry (MassARRAY MALDI-TOF MS). A total of 1,200 genotypes were produced. Allelic and genotypic frequencies and the degree of observed and expected heterozygosities were calculated using the POPGENE software, version 1.32 (Yeh et al. 1999) for each marker. The Hardy-Weinberg equilibrium was tested for each polymorphic marker using a chi square test.

Table 1 Genes, porcine chromosome (SSC), and details of the analyzed polymorphisms

\begin{tabular}{|c|c|c|c|c|}
\hline Gene name (symbol) & $\mathrm{SSC}$ & $\begin{array}{l}\text { Polymorphisms }{ }^{\mathrm{a}} \\
\text { (Amino acid change) }\end{array}$ & Region & References \\
\hline Estrogen receptor 2 (ESR2) & 1 & $\begin{array}{l}\text { AY357117:g.388G }>\text { A } \\
\quad \text { (p.Val317Met) }\end{array}$ & Exon 5 & Muñoz et al. 2004 \\
\hline Alpha-fetoprotein (AFP) & 8 & AY120900:g.547T $>C$ & Intron 10 & Kim et al. 2002 \\
\hline $\begin{array}{l}\text { Bone morphogenetic protein } \\
\text { receptor type I B (BMPRIB) }\end{array}$ & 8 & $\begin{array}{l}\text { AY065994:c. } 960 \mathrm{C}>\mathrm{T} \\
\quad \text { (Silent) }\end{array}$ & Exon 10 & Tomas et al. 2006 \\
\hline Calmegin (CLGN) & 8 & AY536213:g.238A $>G$ & Intron 12 & Kim et al. 2004 \\
\hline $\begin{array}{l}\text { Chemokine (C-X-C motif) } \\
\text { ligand } 10(C X C L 10)\end{array}$ & 8 & AY577902:g.234T $>C$ & Intron 12 & Kim et al. 2004 \\
\hline $\begin{array}{l}\text { Gonadotropin releasing } \\
\text { hormone receptor (GNRHR) }\end{array}$ & 8 & AF227686:g.1721C $>\mathrm{G}$ & 3'-UTR & Jang et al. 2001 \\
\hline $\begin{array}{l}\text { Mannosidase alpha class } \\
2 B \text { member } 2 \text { (MAN2B2) }\end{array}$ & 8 & $\begin{array}{l}\text { D28521:c.1421A }>\text { G } \\
\quad \text { (p.Met475Val) }\end{array}$ & Exon 10 & Campbell et al. 2008 \\
\hline Ring finger protein 4 (RNF4) & 8 & DQ208408:g.358T $>C$ & Intron 5 & Niu et al. 2009 \\
\hline $\begin{array}{l}\text { Porcine Deleted in - AZoospermia } \\
\text { Like ( } p D A Z L)\end{array}$ & 13 & EU430405:g.5999C $>$ A & Intron 9 & Zhang et al. 2009 \\
\hline Retinol Binding protein 4 (RBP4) & 14 & DQ344026:g.447G>C & Intron 4 & Rothschild et al. 2000 \\
\hline
\end{tabular}

\footnotetext{
${ }^{a}$ The nomenclature of the polymorphisms is based on the location of the ATG start codon
} 


\section{Results}

The 10 analyzed genes were chosen by examining the literature for those that were already associated with litter size traits in other pig populations or because they were considered candidates for function and/or chromosomal location. In particular, seven genes map on porcine chromosome (SSC) 8 where QTL for ovulation rate, number of corpora lutea, and uterine capacity were identified (Hu and Reecy 2007). Markers in four out of these seven loci (BMPR1B, GNRHR, MAN2B2, and RNF4) have been previously used in association studies (Campbell et al. 2008; Jang et al. 2001; Niu et al. 2009; Tomas et al. 2006), whereas three (AFP, CLGN, and CXCL10) were considered only for gene mapping in reference families (Kim et al. 2002; 2004). For these three loci, the allelic and genotypic frequencies were not previously obtained in any population (Table 2). Of the analyzed loci, CLGN, encoding a protein essential for sperm fertility, and RFN4, which influences the development of germ cells and oocytes, were not informative in ITLW pigs, as indicated by the presence of only one genotype in the sows. Even the $p D A Z L$ gene, which encodes a protein essential for gametogenesis and has a role in embryo implantation and survival (Zhang et al. 2009), was monomorphic. For the remaining loci, both alleles and the three possible genotypes were detected. For the seven polymorphic genes, the observed heterozygosity ranged from 0.173 $(A F P)$ to 0.530 (RBP4) (Table 2). The differences between the observed and expected heterozygosities were minor and not statistically significant. Among the polymorphic genes of SSC8, AFP, which encodes a major fetal protein (Kim et al. 2004), and BMPRIB, which has an important role in the proliferation and differentiation of granulosa cells and oocytes (Tomas et al. 2006), have minor allele frequencies (MAFs) of 0.10 (g.547C) and 0.44 (c.960T), respectively. The CXCL10 gene, which encodes a chemokine of the CXC family with pleiotrophic effects, including a possible role in embryonic development and implantation (Kim et al. 2004), has a MAF of 0.17 for the g.234C allele. For the GNRHR gene, which regulates the secretion of gonadotropins, we analyzed a polymorphism in the $3^{\prime}$ untranslated region (UTR), 92 bp downstream of the stop codon, with possible effects on mRNA stability. The g.1721G allele of GNRHR showed a frequency of 0.25 . For the $M A N 2 B 2$ gene, which encodes a mannosidase involved in glycosylation of hormones that affect ovulation rate, the allele coding for valine (c.1421G) was more frequent than the allele coding for methionine (c.1421A; frequency of 0.11). The remaining two genes, ESR2,

Table 2 Variability of analyzed loci in a sample of 120 sows of Italian Large White pigs

\begin{tabular}{|c|c|c|c|c|c|c|c|}
\hline \multirow[t]{2}{*}{ Gene symbol } & \multicolumn{2}{|c|}{ Allelic frequencies } & \multicolumn{3}{|c|}{ Genotypic frequencies } & \multirow{2}{*}{$\begin{array}{l}\text { Observed } \\
\text { heterozygosity }\end{array}$} & \multirow{2}{*}{$\begin{array}{l}\text { Expected } \\
\text { heterozygosity }\end{array}$} \\
\hline & Allele 1 & Allele 2 & 11 & 12 & 22 & & \\
\hline ESR2 & G: 0.46 & A: 0.54 & 0.20 & 0.50 & 0.29 & 0.505 & 0.496 \\
\hline$A F P$ & $\mathrm{~T}: 0.90$ & $\mathrm{C}: 0.10$ & 0.82 & 0.17 & 0.01 & 0.173 & 0.171 \\
\hline$B M P R I B$ & $\mathrm{C}: 0.60$ & $\mathrm{~T}: 0.40$ & 0.36 & 0.47 & 0.17 & 0.446 & 0.472 \\
\hline$C L G N$ & A: 1.00 & G: 0.00 & 1.00 & 0.00 & 0.00 & - & - \\
\hline CXCL10 & T: 0.83 & C: 0.17 & 0.69 & 0.28 & 0.03 & 0.277 & 0.282 \\
\hline GNRHR & C: 0.75 & $\mathrm{G}: 0.25$ & 0.56 & 0.38 & 0.06 & 0.356 & 0.373 \\
\hline$M A N 2 B 2$ & A: 0.11 & G: 0.89 & 0.02 & 0.18 & 0.80 & 0.180 & 0.191 \\
\hline RNF4 & $\mathrm{T}: 0.00$ & C: 1.00 & 0.00 & 0.00 & 1.00 & - & - \\
\hline$p D A Z L$ & $\mathrm{C}: 1.00$ & A: 0.00 & 1.00 & 0.00 & 0.00 & - & - \\
\hline$R B P 4$ & G: 0.48 & $\mathrm{C}: 0.52$ & 0.22 & 0.53 & 0.25 & 0.530 & 0.499 \\
\hline
\end{tabular}


coding for one of two estrogen receptors, and $R B P 4$, encoding a retinol-binding protein important in the early stages of pregnancy, showed frequencies close to 0.50 .

\section{Discussion}

The objective of this study was to verify whether polymorphisms in 10 candidate genes for litter size segregate in ITLW pigs. Overall, the data obtained allowed the characterization of the genetic structures of these genes in this pig population. Three loci (CLGN, RNF4, and $p D A Z L)$ were not informative in the genotyped samples. In particular, for $R N F 4$, the only allele present (g.358C) was shown to result in a favorable effect on the number of piglets born alive in a study by Niu et al. (2009). For $p D A Z L$, the allele g.5999C that in Zhang et al. (2009) was associated with the number of piglets born in Large White pig populations in China was fixed in the ITLW pigs. The remaining seven loci were polymorphic, and their reported allelic frequencies added information on the variability of the analysed genes in pigs. Based on these results, the polymorphisms in the AFP, BMPR1B, CXCL10, ESR2, GNRHR, MAN2B2, and RBP4 genes can be considered suitable markers for association studies of litter size in ITLW pigs. The next step will be to analyze these markers in a larger sample of ITLW sows and evaluate their association with prolificacy.

Acknowledgments This work was funded by the MiPAAF SELMOL project.

\section{References}

Campbell EM, Nonneman DJ, Kuehn LA, Rohrer GA (2008) Genetic variation in the mannosidase $2 B 2$ gene and its association with ovulation rate in pigs. Anim Genet 39:515-519

Distl O (2007) Mechanisms of regulation of litter size in pigs on the genome level. Anim Reprod Sci 42:10-16

Hu Z-L, Reecy JM (2007) Animal QTLdb: Beyond a repository-A public platform for QTL comparisons and integration with diverse types of structural genomic information. Mamm Genome 18(1):1-4

Jang Z, Gibson JP, Archibald AL, Haley CS (2001) The porcine gonadotropin-releasing hormone receptor gene $(G N R H R)$ : Genomic organization, polymorphisms, and association with the number of corpora lutea. Genome 44:7-12

Kim JG, Nonneman D, Vallet JL, Christenson RK (2002) Mapping of the porcine alpha-fetoprotein (AFP) gene to swine chromosome 8. Anim Genet 33:471-472

Kim JG, Rohrer GA, Vallet JL, Christenson RK, Nonneman D (2004) Addition of 14 anchored loci to the porcine chromosome 8 comparative map. Anim Genet 35:474-475

Muñoz G, Ovilo C, Amills M, Rodriguez (2004) Mapping of the porcine estrogen receptor 2 gene and association study with litter size in Iberian pigs. Anim Genet 35:242-244

Niu BY, Ye LZ, Li FE, Deng CY, Jiang SW, Lei MG, Xiong YZ (2009) Identification of polymorphism and association analysis with reproductive traits in the porcine RNF4 gene. Anim Reprod Sci 10:283-292

Rothschild MF, Messer L, Day A, Wales R, Short T, Southwood O, Plastow G (2000) Investigation of the retinol-binding protein $4(R B P 4)$ gene as a candidate gene for increased litter size in pigs. Mamm Genome 11:75-77

Tomas A, Frigo E, Casellas J, Ramirez O, Ovilo C, Noguera JL, Sanchez A (2006) An association study between polymorphisms of the porcine bone morphogenetic protein receptor type $1 b(B M P R 1 B)$ and reproductive performance of Iberian $\times$ Meishan $F_{2}$ sows. Anim Genet 37:297-298

Yeh FC, Yang R-C, Boyle T (1999) POPGENE Version 1.32. Microsoft Windows-based Freeware for Population Genetic Analysis. http://www.ualberta.ca/ fyeh

Zhang YH, Meib SQ, Peng XW, Niu BY, Ren ZQ, Zuo B, Xu DQ, Lei MG, Zheng R, Jiang SW, Deng CY, Xiong YZ, Li FE (2009) Molecular characterization and SNPs analysis of the porcine Deleted in AZoospermia Like ( $p D A Z L)$ gene. Anim Reprod Sci 112:415-422 